\title{
Pengembangan Sensor Napas Berbasis Serat Optik Plastik dengan Cladding Terkelupas untuk Aplikasi di Bidang Medis
}

\author{
Wayan Suana* \\ a. Jurusan Fisika-FMIPA, Institut Teknologi Sepuluh Nopember, Kampus ITS Sukolilo, Surabaya 61111 \\ b. Jurusan Pendidikan Fisika-FKIP, Universitas Lampung \\ Jl. Sumantri Brojonegoro No. 1, Gedung Meneng, Bandar Lampung 35145 \\ Melania S. Muntini \\ Jurusan Fisika-FMIPA, Institut Teknologi Sepuluh Nopember, Kampus ITS Sukolilo, Surabaya 61111 \\ Agus M. Hatta \\ Jurusan Teknik Fisika-FTI, Institut Teknologi Sepuluh Nopember \\ Kampus ITS Sukolilo, Surabaya 61111
}

\begin{abstract}
Intisari
Telah dihasilkan sensor napas untuk memantau kondisi pernapasan manusia menggunakan serat optik plastik jenis multimode step index. Probe sensor napas sepanjang $10 \mathrm{~cm}$ dibuat dengan mengupas cladding serat optik sepanjang $3 \mathrm{~cm}$ dibagian tengah probe. Perbedaan temperatur dan kelembaban antara udara inspirasi dengan udara ekspirasi menimbulkan perubahan indeks bias udara yang melingkupi probe sensor, dan mengakibatkan absorpsi medan evanescent yang berbeda sehingga menghasilkan keluaran sensor. Hasil pengukuran menunjukkan bahwa pengaruh kelembaban lebih dominan dibandingkan pengaruh temperatur. Penurunan keluaran sensor yang diakibatkan oleh kelembaban pada rentang kelembaban relatif udara napas $(83,7-85,4) \%$ adalah 0,653 volt, sedangkan kenaikan keluaran sensor yang diakibatkan oleh temperatur pada rentang temperatur udara napas $(29,8-30,6){ }^{\circ} \mathrm{C}$ adalah 0,023 volt. Hasil pengujian probe sensor napas dalam mendeteksi beberapa kondisi pernapasan menunjukkan bahwa probe sensor napas dapat mendeteksi kondisi pernapasan biasa, pernapasan terengah-engah, dan batuk. Rata-rata selisih keluaran maksimum minimum sensor pada pernapasan biasa, terengah-engah, dan batuk berturut-turut adalah 1,012 volt, 2,157 volt, dan 4,026 volt.
\end{abstract}

KATA KUNCI: cladding, evanescent, sensor napas, serat optik

\section{PENDAHULUAN}

Pernapasan merupakan fungsi fisiologis yang sangat penting. Dari pernapasan dapat diperoleh informasi tentang kondisi fisik pasien, termasuk tentang indikasi penyakit yang dideritanya, misalnya pneumothorax atau gangguan paru-paru kronis [1]. Selain itu, pemantauan kondisi pernapasan pasien pada proses pencitraan dalam ruang MRI, pembiusan pasien, bayi yang menderita sindrom meninggal tiba-tiba, dan pasien yang menderita sleep apnea, juga penting dilakukan untuk mengetahui kondisinya setiap saat [2].

Sejauh ini, telah dikembangkan beberapa macam sensor berbasis serat optik plastik untuk memantau kondisi pernapasan manusia. Sebagai sensor, serat optik plastik memiliki beberapa kelebihan, yaitu mudah dimodifikasi, relatif murah, tahan terhadap interferensi medan listrik maupun medan magnet, dan konsumsi daya yang rendah [3-5]. Sensor napas berbasis serat optik yang telah dibuat, yaitu dengan memanfaatkan aliran udara pernapasan, dan pergerakan otot perut

*E-MAIL: wsuane@gmail.com dan otot dada. Sensor napas yang memanfaatkan aliran udara pernapasan dibuat dengan mengukur temperatur $[1,6]$, kelembaban [7, 8], dan gas $\mathrm{CO}_{2}$ dalam udara pernapasan [9]. Sebagian besar sensor napas jenis ini memerlukan material tambahan sebagai pengganti cladding atau sebagai penyerap panas. Sementara itu, sensor napas yang memanfaatkan pergerakan otot perut bekerja dengan mengukur perubahan intensitas cahaya terpandu karena perubahan jari-jari tekukan serat optik $[2,6,10]$. Sensor jenis pertama memerlukan serat optik yang relatif panjang sehingga biayanya menjadi lebih mahal sedangkan jenis kedua proses pembuatannya lebih rumit.

Di sisi lain, udara pernapasan memiliki kelembaban dan temperatur yang berubah-ubah. Udara ekspirasi lebih lembab daripada udara inspirasi karena udara ekspirasi berasal dari alveolus yang lembab [11]. Selain itu, udara ekspirasi juga temperaturnya tinggi daripada udara inspirasi $[6,10]$. Oleh karena nilai indeks bias udara turut dipengaruhi oleh temperatur dan kelembaban $[12,13]$, maka indeks biasnya akan berubah-ubah selama orang bernapas. Perubahan indeks bias udara pernapasan dapat dimanfaatkan untuk membuat sensor napas berbasis serat optik dengan cladding dikupas dan digantikan oleh udara pernapasan yang melingkupinya.

Birch [13] menyatakan bahwa persamaan indeks bias udara 


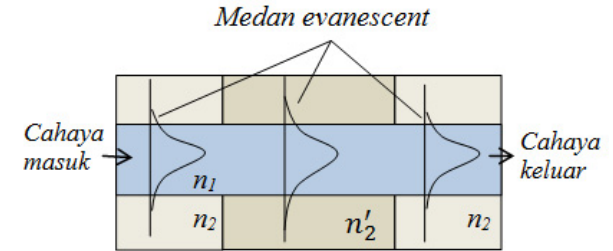

Gambar 1: Medan evanescent.

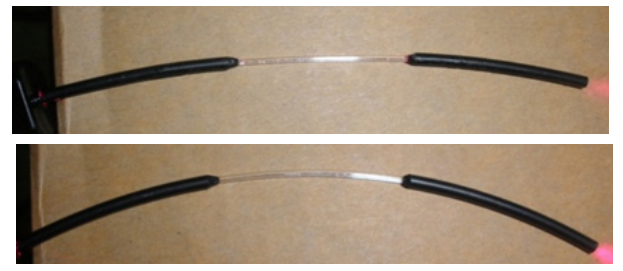

Gambar 2: (a) Probe sensor napas, (b) Probe sensor pembanding. pada keadaan standar dari hasil koreksinya terhadap perumusan Edlen adalah:

$$
(n-1)_{s} \times 10^{8}=a+\frac{2406294}{130-k^{2}}+\frac{15999}{38,8-k^{2}}
$$

dengan $\mathrm{a}=8343,05$ dan $\mathrm{k}$ adalah bilangan gelombang pada keadaan vakum $\left(\mu \mathrm{m}^{-1}\right)$. Keadaan standar yang dinyatakan oleh Birch adalah keadaan udara pada temperatur $20^{\circ} \mathrm{C}$, tekanan $100 \mathrm{KPa}$, kelembaban $50 \%$, dan kadar $\mathrm{CO}_{2} 450$ ppm. Pada keadaan tidak standar, persamaan indeks bias yang bergantung temperatur dan tekanan dinyatakan sebagai [13]:

$$
(n-1)_{T P}=\left(\frac{P(n-1)_{s}}{96095,43}\right)\left(\frac{1+b P}{1+0,0036610 T}\right)
$$

dengan $b=(0,601-0,00972 T) \times 10^{-8}$. Pada Pers.(2) tampak bahwa pada tekanan tetap, semakin tinggi temperatur udara maka semakin rendah indeks biasnya.

Kelembaban juga berpengaruh terhadap indeks bias udara. Persamaan indeks bias udara setelah dikoreksi akibat adanya pengaruh kelembaban adalah [13]:

$$
n_{T P f}=n_{T P}-f(3,734-0,0401) \times 10^{-10}
$$

dengan $\mathrm{n}_{T P f}$ adalah indeks bias udara setelah memperhitungkan faktor temperatur, tekanan, dan kelembaban udara. Pengaruh kelembaban diwakili oleh $\mathrm{f}$, yaitu tekanan parsial uap air dalam udara (Pa). Pers.(3) menunjukkan bahwa semakin tinggi f, yang berarti kelembaban udara semakin tinggi, maka indeks biasnya menjadi semakin kecil.

Sensor napas yang dibuat pada penelitian ini prinsip kerjanya berdasarkan fenomena absorpsi medan evanescent (evanescent field). Fenomena medan evanescent muncul dari kenyataan bahwa ketika cahaya merambat sepanjang serat optik, medan listrik cahaya tersebut tidak sepenuhnya berada pada daerah core serat optik namun sebagian masuk di daerah cladding. Bagian medan listrik yang berada di daerah cladding itulah yang disebut dengan medan evanescent [3]. Gambar 1 menunjukkan medan evanescent pada serat optik. Ketika cahaya merambat pada serat optik dengan indeks $n_{2}$ yang berbeda maka intensitas medan evanescent yang terserap mengalami perubahan.

Amplitudo medan evanescent mengalami peluruhan secara eksponensial terhadap jarak dari bidang batas core dan cladding serat optik, dinyatakan dengan [14]:

$$
E_{z}=E_{\circ} \exp \left(\frac{z}{d_{p}}\right)
$$

dengan $\mathrm{z}$ adalah jarak penjalaran sinar, $\mathrm{E}_{\circ}$ adalah medan gelombang awal, dan $\mathrm{d}_{p}$ kedalaman penetrasi medan evanescent.

Kedalaman penetrasi $\left(\mathrm{d}_{p}\right)$ medan evanescent adalah [14]:

$$
d_{p}=\frac{\lambda}{2 \pi n_{1} \sqrt{\sin ^{2} \theta-\left(\frac{n_{2}}{n_{1}}\right)^{2}}}
$$

dengan $\lambda$ adalah panjang gelombang cahaya, $\mathrm{n}_{1}$ adalah indeks bias core, $\mathrm{n}_{2}$ adalah indeks bias cladding, dan $\theta$ merupakan sudut datang pada bidang batas core dan cladding serat optik. Tampak bahwa kedalaman penetrasi medan evanescent bergantung pada nilai indeks bias cladding relatif terhadap indeks bias core. Apabila indeks bias cladding serat optik berubah maka kedalaman penetrasi medan evanescent juga berubah. Semakin dalam penetrasi medan evanescent semakin kecil intensitas cahaya yang terpandu.

\section{METODE PENELITIAN}

Probe sensor dibuat dari serat optik plastik jenis multimode step index dengan spesifikasi diameter core $0,98 \mathrm{~mm}$, diameter cladding $1 \mathrm{~mm}$, indeks bias core 1,49, dan NA 0,5. Probe sensor dibuat sepanjang $10 \mathrm{~cm}$. Jaket dan cladding probe sensor dikupas sepanjang $3 \mathrm{~cm}$ tepat di bagian tengahnya. Pengupasan jaket dilakukan dengan pisau sedangkan pengupasan cladding menggunakan campuran aseton dan alkohol dengan perbandingan 9:1. Setelah itu, probe sensor dibiarkan mengering pada temperatur ruang selama sekitar 2 jam. Probe sensor ditunjukkan oleh Gambar 2 (a). Sebagai pembanding, dibuat probe sensor lain yang sejenis namun tanpa pengupasan cladding, Gambar 2 (b).

Sebelum sensor digunakan untuk mendeteksi pernapasan yang direpresentasikan dalam bentuk tegangan, terlebih dahulu dilakukan pengukuran-pengukuran awal. Pengukuran awal meliputi pengukuran parameter fisis pada udara pernapasan, dan pengukuran pengaruh temperatur dan kelembaban terhadap respon sensor. Parameter fisis yang diukur adalah temperatur, kelembaban, dan tekanan udara, dengan alat ukur berturut-turut adalah termokopel, SHT11, dan barometer. Sementara itu, pengukuran pengaruh temperatur dan kelembaban dilakukan dalam ruang uji (chamber) berukuran $(23 \times$ $23 \times 26) \mathrm{cm}^{3}$. Saat mengukur pengaruh temperatur, kelembaban dipertahankan konstan dengan cara mengatur pelembab udara (humidifier). Sementara saat mengukur pengaruh kelembaban, temperatur yang dipertahankan konstan dengan 


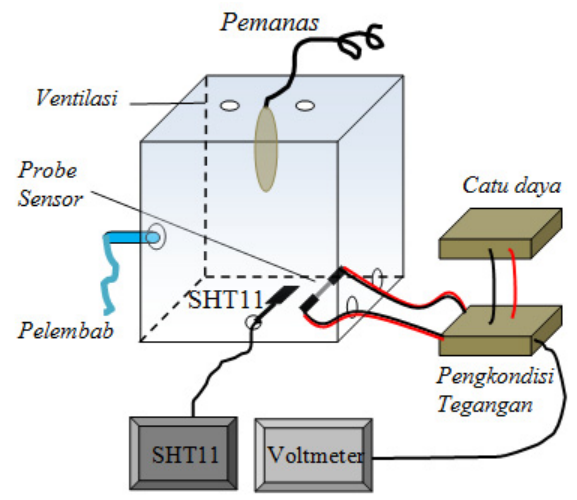

Gambar 3: Rangkaian pengujian temperatur dan kelembaban.

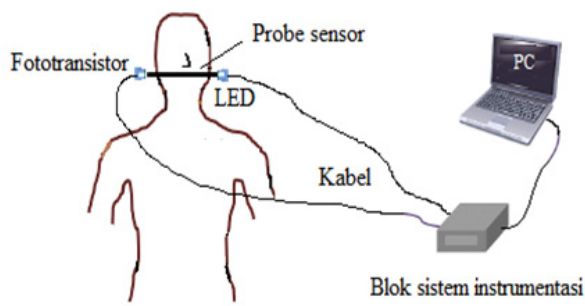

Gambar 4: Rangkaian pengujian sensor napas.

cara mengatur elemen pemanas. Sumber cahaya yang digunakan adalah LED inframerah jenis IF-E91A sedangkan detektornya adalah fototransistor jenis IF-D92 (industrial Fiber Optics). Rangkaian uji pengaruh temperatur dan kelembaban ditunjukkan oleh Gambar 3.

Pengujian probe sensor untuk mendeteksi pernapasan dilakukan pada tiga jenis pernapasan, yaitu pernapasan biasa, pernapasan terengah-engah, dan pernapasan dengan batuk. Pernapasan biasa merupakan pernapasan seseorang dalam kondisi santai atau istirahat. Pernapasan terengah-engah yaitu pernapasan seseorang setelah melakukan aktivitas fisik berlari ditempat selama 5 menit. Probe sensor diletakkan pada masker lalu dihubungkan dengan blok rangkaian instrumentasi. Pada pengujian ini akuisisi data dilakukan oleh mikrokontroler dan hasilnya ditampilkan melalui PC. Rangkaian pengujian sinyal pernapasan ditunjukkan oleh Gambar 4.

\section{HASIL PENGUJIAN AWAL}

Hasil pengukuran parameter fisis udara pada pernapasan biasa ditunjukkan Gambar 5. Tampak bahwa temperatur dan kelembaban relatif mengalami perubahan sementara tekanan tidak mengalami perubahan. Temperatur dan kelembaban relatif meningkat saat ekspirasi disebabkan karena udara saat ekspirasi berasal dari dalam paru-paru yang lebih lembab dan lebih hangat dibandingkan udara lingkungan. Jangkauan temperatur hasil pengukuran adalah $(29,8-30,6)^{\circ} \mathrm{C}$ sedangkan rata-rata selisih temperatur maksimum dengan temperatur

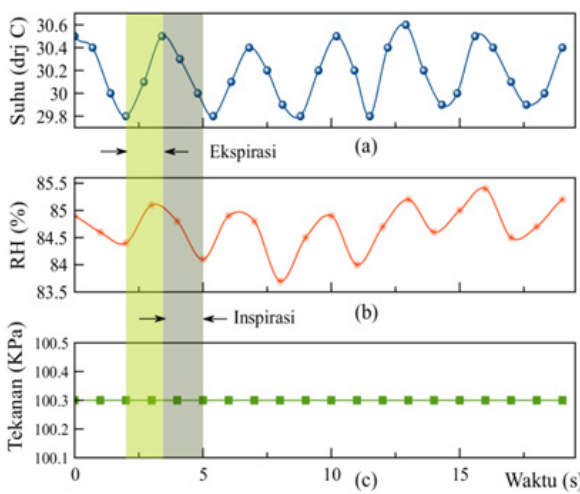

Gambar 5: Hasil pengukuran parameter fisis udara pernapasan,(a) temperatur,(b) kelembaban relatif,dan (c) tekanan.

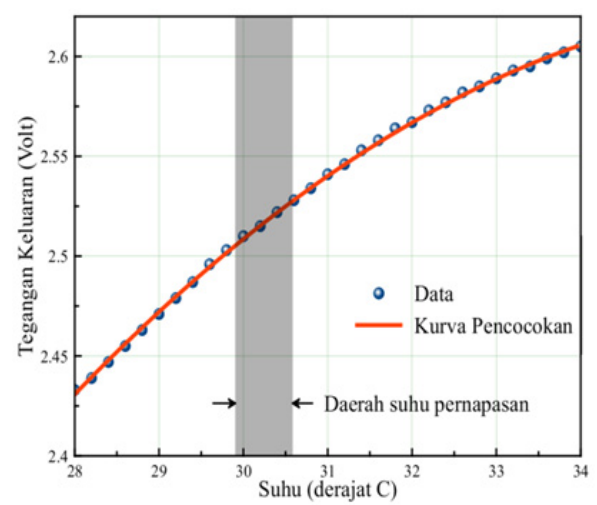

Gambar 6: Pengaruh temperatur terhadap keluaran sensor napas.

minimum untuk enam kali napas adalah $0,67^{\circ} \mathrm{C}$. Jangkauan hasil pengukuran kelembaban adalah $(83,7$ - 85,4)\% sedangkan rata-rata selisih kelembaban relatif maksimum dan minimumnya $0,85 \%$. Sementara itu, dengan barometer yang memiliki nilai skala terkecil $0,1 \mathrm{KPa}$ memberi hasil pengukuran tekanan udara yang tidak berubah, 100,3 KPa.

Hasil pengukuran pengaruh temperatur terhadap keluaran sensor ditunjukkan oleh Gambar 6. Keluaran sensor mengalami kenaikan saat temperatur udara dinaikkan. Rata-rata kelembaban relatif dalam ruang uji adalah $70,2 \%$ sedangkan tekanan tidak mengalami perubahan, yaitu 100,4 KPa. Ketika temperatur udara berubah maka terjadi perubahan indeks bias core sensor $\left(\mathrm{n}_{1}\right)$ dan indeks bias udara yang melingkupinya $\left(\mathrm{n}_{2}\right)$. Semakin tinggi temperatur, $\mathrm{n}_{1}$ menjadi semakin besar sedangkan $\mathrm{n}_{2}$ menjadi semakin kecil. Hal ini menyebabkan $\mathrm{d}_{p}$ menjadi kecil. Semakin kecil $\mathrm{d}_{p}$, penyerapan medan evanescent menjadi semakin menurun. Menurunnya penyerapan medan evanescent mengakibatkan cahaya yang terpandu pada serat optik mengalami peningkatan dan pada akhirnya menaikkan tegangan keluaran sensor.

Pencocokan kurva didekati dengan persamaan parabola, $y(x)=-0,002 x^{2}+0,165 x-0,457$ dengan y adalah keluaran sensor (volt) dan $\mathrm{x}$ adalah temperatur $\left({ }^{\circ} \mathrm{C}\right)$. Sensitivitas sensor (b) merupakan kemiringan dari kurva dan nilainya bergantung pada $x$. Sensitivitas diperoleh dengan mendef- 


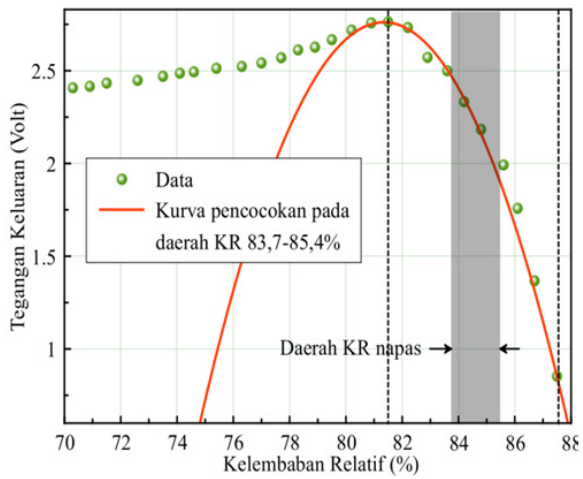

Gambar 7: Pengaruh kelembaban relatif terhadap keluaran sensor napas pada temperatur $27,2-27,3{ }^{\circ} \mathrm{C}$.

erensialkan persamaan pencocokan kurva, $\mathrm{b}(\mathrm{x})=-0,004 \mathrm{x}+$ 0,165 . Pada daerah temperatur napas $(29,8-30,6)^{\circ} \mathrm{C}$, keluaran sensor naik 0,023 volt.

Sementara itu, hasil pengukuran pengaruh kelembaban terhadap keluaran sensor ditunjukkan oleh Gambar 7. Pada daerah kelembaban relatif $(70,2-81,5) \%$, keluaran sensor mengalami kenaikan. Kenaikan ini disebabkan oleh turunnya indeks bias $\mathrm{n}_{2}$. Pada temperatur tetap, indeks bias udara turun ketika kelembabannya meningkat. Turunnya $\mathrm{n}_{2}$ membuat kedalaman penetrasi mengecil. Semakin kecil kedalaman penetrasi, semakin besar medan evanescent yang terpandu sehingga membuat keluaran sensor menjadi naik. Berlawanan dengan hasil yang diperoleh pada daerah kelembaban relatif $(70,2-81,5) \%$, pada kelembaban relatif $(81,5-87,7) \%$ keluaran sensor justru turun secara drastis. Penurunan tersebut mengindikasikan adanya kenaikan indeks bias $\mathrm{n}_{2}$. Uap air mengalami pengembunan dan menempel pada permukaan probe sensor. Indeks bias air lebih besar dari indeks bias udara maka indeks bias cladding berubah dari indeks bias udara ke indeks bias air, akibatnya keluaran sensor turun secara drastis. Semakin tinggi kelembaban relatif, semakin banyak permukaan probe sensor yang tertutupi titik-titik air.

Pencocokan kurva pada rentang kelembaban relatif $(81,5$ - 87,7)\% didekati dengan persamaan parabola, yaitu dengan persamaan $\mathrm{y}(\mathrm{x})=-0,056 \mathrm{x}^{2}+9,154 \mathrm{x}-371,500$ dengan $\mathrm{y}$ adalah keluaran sensor (volt), dan $\mathrm{x}$ adalah kelembaban relatif (\%). Sementara itu, sensitivitas sensor dalam rentang tersebut, (b) merupakan fungsi dalam $x$, yaitu $b(x)=-0,112 x+$ 9,154 . Penurunan keluaran sensor pada daerah kelembaban relatif napas adalah 0,653 volt, lebih tinggi dari kenaikan yang disebabkan temperatur.

\section{HASIL PENGUKURAN SINYAL PERNAPASAN}

Hasil pengujian sensor untuk mengukur pernapasan biasa ditunjukkan oleh Gambar 8. Sensor mampu mendeteksi pola sinyal pernapasan manusia. Saat inspirasi sensor menghasilkan keluaran yang meninggi, dan saat ekspirasi sensor menghasilkan keluaran yang menurun. Rata-rata selisih keluaran maksimum saat inspirasi dengan keluaran minimum saat

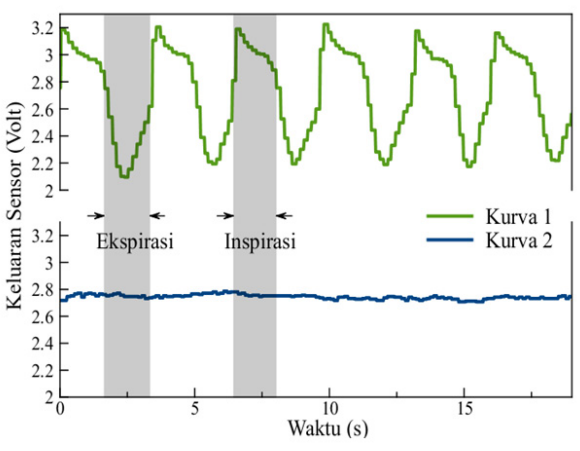

Gambar 8: Keluaran Sensor.

ekspirasi adalah 1,012 volt. Hasil keluaran sensor yang menurun saat ekspirasi sesuai dengan hasil pengujian pengaruh kelembaban relatif terhadap keluaran sensor. Hal ini menunjukkan bahwa pengaruh kelembaban lebih dominan terhadap keluaran sensor dibandingkan pengaruh temperatur. Seperti yang diperoleh dari hasil pengukuran awal, kelembaban relatif udara pada pernapasan biasa berada pada rentang $(83,7$ $85,4) \%$. Pada daerah kelembaban relatif tersebut, permukaan sensor terlapisi oleh titik-titik air. Semakin lembab udaranya, semakin luas bagian permukaan sensor yang terlapisi titiktitik air sehingga membuat semakin sedikit cahaya yang terpandu dalam sensor sehingga keluaran sensor menurun. Titiktitik air yang melapisi permukaan sensor cepat mengering sehingga ketika udara pernapasan berhenti dihembuskan, keluaran sensor langsung naik.

Kurva 2 pada Gambar 8 merupakan hasil keluaran oleh probe sensor pembanding, yang dibuat dari bahan, panjang serat optik, dan panjang kupasan jaket yang sama tetapi cladding asli serat optiknya tidak dikelupas. Dengan demikian, indeks bias $\mathrm{n}_{2}$ adalah indeks bias cladding asli serat optik. Tampak bahwa keluaran sensor ini cenderung konstan baik saat inspirasi maupun ekspirasi. Hasil ini menunjukkan bahwa tanpa adanya pengelupasan cladding asli serat optik, probe sensor tidak bisa mendeteksi sinyal pernapasan. Ketika cladding asli serat optik tidak dikelupas, pengaruh kelembaban maupun temperatur dari udara pernapasan menjadi tidak nampak. Hasil sensor pembanding ini juga menunjukkan bahwa pengaruh adanya noise yang mungkin muncul karena faktor-faktor yang tidak teramati, tidak mempengaruhi keluaran sensor secara signifikan.

Gambar 9 menunjukkan perbandingan sinyal pernapasan biasa dengan sinyal pernapasan terengah-engah. Dalam waktu yang sama (19 detik), jumlah napas untuk pernapasan terengah-engah (12 kali napas) lebih banyak daripada jumlah napas untuk pernapasan biasa (6 kali napas). Saat kelelahan, orang bernapas lebih cepat dari biasanya untuk memperoleh gas oksigen yang cukup untuk proses respirasinya. Selain frekuensinya lebih cepat, amplitudo pernapasan terengahengah juga lebih besar daripada pernapasan biasa. Rata-rata amplitudo untuk pernapasan biasa adalah 2,157 volt, sekitar dua kali dari amplitudo pernapasan biasa. Hal ini menunjukkan bahwa sensor memiliki sensitivitas dan waktu respon yang baik sehingga mampu mengukur sinyal pernapasan den- 


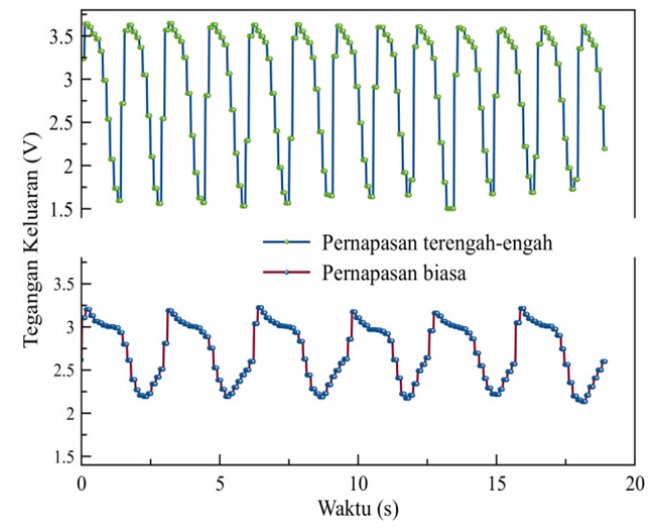

Gambar 9: Perbandingan sinyal pernapasan biasa dengan pernapasan terengah-engah.

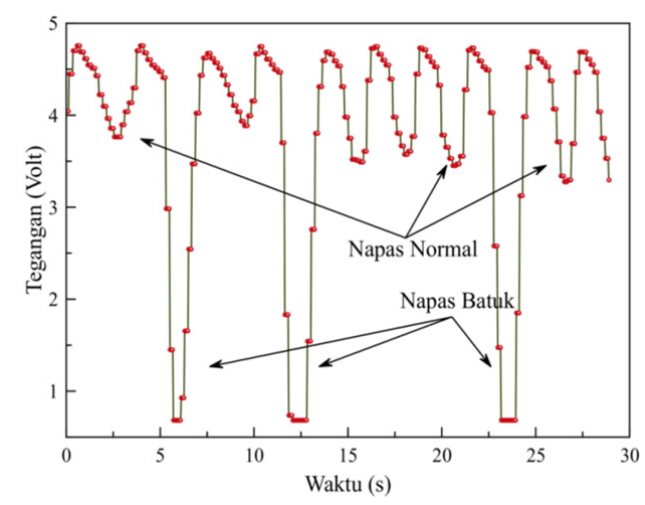

Gambar 10: Sinyal pernapasan dengan batuk.

gan frekuensi yang lebih cepat dari biasanya.

Hasil keluaran sensor untuk mengukur sinyal pernapasan yang disertai batuk ditunjukkan oleh Gambar 10. Tampak bahwa saat batuk, keluaran sensor turun jauh menjadi 0,708 volt. Rata-rata selisih keluaran maksimum saat inspirasi dengan keluaran minimum saat ekspirasi adalah 4,026 volt. Pada saat batuk, volume udara yang dikeluarkan lebih banyak sehingga keluaran sensor menjadi lebih jauh turunnya. Pada hasil pengukuran ini, jumlah batuk dapat dihitung dengan mudah, yaitu tiga kali. Dengan demikian, sensor dapat membe- dakan sinyal batuk dengan sinyal pernapasan biasa.

\section{SIMPULAN}

Pada pengukuran parameter fisis udara pernapasan diperoleh rentang temperatur $(29,8-30,6)^{\circ} \mathrm{C}$, rentang kelembaban relatif $(83,7-85,4) \%$ sedangkan tekanannya tidak berubah. Pada rentang temperatur tersebut, keluaran sensor napas naik 0,023 volt sedangkan pada rentang kelembaban relatif, keluaran sensor turun 0,653 volt. Penurunan keluaran sensor yang disebabkan oleh pengaruh kelembaban lebih besar nilainya dibandingkan dengan peningkatan keluaran sensor yang disebabkan oleh pengaruh temperatur. Hal ini menunjukkan bahwa keluaran sensor napas lebih dominan dipengaruhi oleh kelembaban daripada temperatur. Sementara dari hasil pengujian sensor dalam mendeteksi pernapasan biasa, pernapasan terengah-engah, dan batuk menunjukkan bahwa sensor dapat mendeteksi dan membedakan ketiga jenis pernapasan tersebut. Pada pernapasan biasa keluaran sensor naik saat inspirasi dan turun saat ekspirasi dengan selisih keluaran maksimum minimumnya 1,012 volt. Hasil pengujian sensor dalam mendeteksi pernapasan terengah-engah menunjukkan bahwa sensor napas memiliki waktu respon yang singkat sehingga dapat mendeteksi pernapasan dengan frekuensi sekitar dua kali lebih cepat dari pernapasan biasa. Rata-rata selisih keluaran maksimum-minimum sensor pada pernapasan terengah-engah juga lebih besar daripada pernapasan biasa, yaitu 2,157 volt. Pengujian sensor napas dalam mendeteksi batuk menunjukkan bahwa sensor dapat membedakan saat batuk dengan saat bernapas biasa. Ketika batuk, keluaran sensor turun drastis dengan rata-rata selisih keluaran maksimumminimumnya 4,026 volt.

\section{Ucapan Terima Kasih}

Ucapan terimakasih kami sampaikan kepada Ditjen Dikti atas bantuan dana untuk penelitian ini melalui BPPS. Terimakasih juga kami ucapkan kepada Ketua Jurusan Fisika beserta staf, dan kepada Kepala Laboratorium Elektronika dan Instrumentasi Fisika ITS atas kesempatan yang diberikan untuk melakukan penelitian ini.
[1] Y.Liang, et al., Fibre Bragg Grating Sensor for Respiratory Monitoring, ACOFT/AOS 2006-Proc., Melbourne Australia, 2006.

[2] J. Witt, et al., Sensor Journal, IEEE, 12, 246 (2011).

[3] F.T.S. Yu, and S. Yin, Fiber Optic Sensors (Marcel Dekker Inc, New York, 2002).

[4] J. Crisp, Introduction to Fiber Optics (Newnes, Oxford, 2001).

[5] M.G. Kuzyk, Polymer Fiber Optics (Taylor \& Francis Group LLC, Boca Raton USA, 2007).

[6] W.J. Yoo, et al., Optical Society of Korea, 14, 235 (2010).

[7] M. Morisawa, and S. Muto, A Novel Breathing Condition Sensor Using Plastic Optical Fiber, Sensors, 2004. Proceedings of IEEE, 3, 1277, 2004.

[8] Q. Chen, et al., Optical Fiber Sensors for Breathing Diagnostics,
IEEE Optical Fiber Sensors Conference Technical Digest, 15th, 1, 273, 2002.

[9] W. J. Yoo, et al., Chalcogenide Optical Fiber Based Sensor for Non-Invasive Monitoring of Respiration, IEEE Symposium on Industrial Electronics and Applications (ISIEA), 2009.

[10] W.J.Yoo, et al., Korean Physical Society, 57, 1550 (2010).

[11] R.D. Allen, Biology, A Critical Thinking Approach (WCB Publishers, USA, 1995).

[12] B. Edlen, Metrologia 2, 71 (1966).

[13] K.P. Birch, and M.J. Downs, Metrologia, 30, 155 (1993).

[14] T.L. Yeo, J. of Sensors and Actuators A, 144, 280 (2008). 